Article

\title{
New Urbanism and Contextual Relativity: Insights from Sweden
}

\author{
Crystal Filep ${ }^{1}$ and Michelle Thompson-Fawcett ${ }^{2, *}$ \\ ${ }^{1}$ Urban Design Office, Wellington City Council, 6140, Wellington, New Zealand; E-Mail: crystal.filep@wcc.govt.nz \\ 2 Te Iho Whenua School of Geography, University of Otago, 9054, Ōtepoti Dunedin, New Zealand; \\ E-Mail: mtf@geography.otago.ac.nz \\ * Corresponding author
}

Submitted: 28 July 2020 | Accepted: 22 October 2020 | Published: 22 December 2020

\begin{abstract}
Contextual relativities in the diversifying expression of New Urbanism are increasingly important. In this article, we explore the significance of context using a Scandinavian setting as example. We examine two embodiments of the Swedish realisation of New Urban neighbourhoods. Important in our exploration are the relationalities with contemporary contexts and belief systems, since every effort to create space becomes "an elaboration of the beliefs and values of some collection of people, expressed and fostered in their promotion of a preferred reality" (Stokowski, 2002, p. 374). The findings from the study demonstrate that the Swedish New Urban neighbourhood-no matter how meaningful as a communicative form mediating between agents and structures-cannot effect social cohesion or isolation. Rather, form communicates or evokes meaning in a variety of complex ways, suggesting the importance of "look[ing] to multiply...our readings of the city" (Leach, 1997, p. 158), particularly high-level readings that echo notions of the common good. Those concerned with New Urbanism's embodiments should deliberate on relational fluidities and thereby strike a balance between conceptualising such urban design as either deterministically exceeding its power (Lawhon, 2009) or as side-lined to the whimsical relativity of particular consumers (Latham, 2003; Smith, 2002).
\end{abstract}

\section{Keywords}

compact neighbourhoods; good community; neighbourhood planning; New Urbanism; Sweden

\section{Issue}

This article is part of the issue "New Urbanism: From Exception to Norm-The Evolution of a Global Movement" edited by Susan Moore (University College London, UK) and Dan Trudeau (Macalester College, USA).

(C) 2020 by the authors; licensee Cogitatio (Lisbon, Portugal). This article is licensed under a Creative Commons Attribution 4.0 International License (CC BY).

\section{Introduction}

In this article we examine how the New Urban neighbourhood is conceptualised and experienced in Sweden, so as to contribute to wider deliberations about the relevance of a historically-derived form in relation to emergent-and sometimes divergent-notions of contemporary sociality and meaningful coexistence. Two case studies-Sankt Erik and Hammarby Sjöstadwere chosen because they exemplify the formal goals of New Urbanism's neighbourhood planning efforts, yet exist within a social context quite different from those that New Urban protagonists are used to operating within: Sweden. Stockholm presented a unique opportunity for an investigation with some distance from where the popular New Urbanism discourses and processes are being most prominently experienced in Britain and North America (Marcus, Balfors, \& Haas, 2013).

A particular objective of the article is to challenge dominant notions of the good community as a necessary but elusive target for achieving the common good urban life in both New Urbanism discourse and critique. Current conceptions and critiques tend to overlook the power of both practitioners and residents in relation to dominant discourses and structures. Therefore, we argue the need for a relationally nuanced investigation that recognises the mediative role of urban architectureparticularly that which is formally cohesive-between human agents and larger contexts. 
The neighbourhood has been conceptualised in dominant New Urbanism discourse as an architectural body intertwined with certain notions of an idealised social body. It can be understood as a communicative form that prompts the individual inhabitant to enter into a certain kind of relationship both with those designers who conceptualised or are conceptualising it, and with all those who, simultaneously, previously, or subsequently, experience life in relation to the same form.

Furthermore, New Urban neighbourhood form can be typologically identified by four essential characteristics: (1) standardised and (2) walkable, featuring (3) a central public space and (4) cohesive architecture. The neighbourhood is of interest in this study because, as a formal typology comprised of these four characteristics espoused by New Urbanists, it can be understood as a widely-adopted building block of contemporary cities (Lawhon, 2009).

From the 1990s onward, protagonists of The Congress for New Urbanism in America and Urban Villages Forum in Britain have led a resurgence of the use of this formal type as an idealised alternative to Modernist planning efforts. The "extensive multidirectional exchange" of New Urbanism discourse across the Atlantic (Thompson-Fawcett, 2003a, p. 253) and, later, to other parts of the globe has led to widespread variations of the form being adopted in a multitude of cultural contexts-more recently through bolstered exchange networks and derivative groups-such as The Smart Growth Network, The Original Green, The International Network for Traditional Building, Architecture and Urbanism, Council for European Urbanism, and The Prince's Foundation for Building Community. The New Urban neighbourhood type has been adopted broadly as an ideal form of good urban development (Ancell \& Thompson-Fawcett, 2008; Keyes, 2015).

Any reevaluation of the New Urban neighbourhood should consider the ability of urban form to communicate with "us by intensifying and densifying the world" (Knausgaard, 2015), but do so in a way that allows developments, their designers and inhabitants to stand-at least somewhat-independent of dominant New Urbanism discourse and its critique. Such independent inquiry allows for new and emerging communicative capacities of the urban neighbourhood to be unveiled and shared. Recent impulses within human geography, urban planning and landscape architecture, as well as a cultural context under-examined in relation to New Urbanist efforts emanating from Britain and North America, offer the possibility of such inquiry. The primary investigative aim is to challenge how and why urban neighbourhoods are conceptualised in both theory and practice-particularly in relation to the geographically-bound community-and thereby advance notions of the common good life in relation to urban form. By re-evaluating neighbourhood conceptions and experiences in this way, fresh questions can be posited about how human beings best live together, particularly within the rapidly expanding and increasingly plural metropolitan landscapes of this century.

Our investigation emphasises professional practitioner conceptions and residential lived experiences within the Swedish context so as to inform and influence dominant New Urbanism discourse and related efforts to achieve formal-social relationships that approximate notions of the good urban life.

The discourse of New Urbanism is multifarious and evolving, so our general understanding of its core foundations is built on the works of key protagonists and expounders, including the Congress for the New Urbanism (particularly the Charter of the New Urbanism [1996] and The 25 Great Ideas of the New Urbanism [2018]), Andres Duany, Elizabeth Plater-Zyberk, Leon Krier, Robert Steuteville, Peter Katz, Stefanos Polyzoides, Jeff Speck, Hank Dittmar, Emily Talen, and others. In early and recent works by such authors, we recognise an enduring thread linking form and sociality: It is a movement that seeks "reinvestment in design, community, and place," believing that well-designed places "help create community" (Congress for the New Urbanism, n.d.). It pursues "reconfiguration of sprawling suburbs into communities"; "community stability" sustained by a "coherent and supportive physical framework"; neighbourhoods that "form identifiable areas that encourage citizens to take responsibility for their maintenance and evolution"; neighbourhoods that strengthen "the personal and civic bonds essential to an authentic community"; streets and squares that "enable neighbors to know each other and protect their communities"; places that "reinforce community identity and the culture of democracy"; all combined with specific delineations of urban design that will contribute to the achievement of such sociality (Congress for the New Urbanism, 1996).

Choosing Swedish case studies to contextualise an examination of New Urbanism in terms of form and sociality is beneficial from the perspective of iluminating heterogeneous, partial translations of the movement. Stockholm is home to some of the world's most quintessential realisations of compact neighbourhood form from the early $20^{\text {th }}$ century, particularly that credited to Per Olof Hallman, a student of Camillo Sitte (Elmlund \& Martelius, 2015). Sitte had a great deal of influence over his Garden City contemporaries (Collins \& Collins, 1986; Porfyriou, 1992; Sonne, 2009), and their collective efforts have in turn influenced the New Urbanism movement, in terms of both its formal and social goals. Nevertheless, the compact neighbourhood form they espoused was "regarded as a building pattern rather than a social concept" in early$20^{\text {th }}$-century Sweden (Hall, 1994, p. 165). Similarly and despite Krier's frequent presence at Stockholm's stad (Stockholm Municipality) during the 1990s (Wolodarski, personal communication), “New Urbanism's neighbourhood planning...has neither been accepted nor transferred to Sweden, at least not in its entirety" (Marcus 
et al., 2013, p. 75). In Sweden, people have a strong collective memory of enduring "contradictions and unintended consequences" of a welfare state (Trägårdh, 1990, p. 570) and religious severity (Demerath, 2000), and thus are wary of social dogmas. In other words, Sankt Erik and Hammarby Sjöstad exemplify formal characteristics of New Urbanism, while their situatedness in Stockholm reinforces the possibility of revealing new understandings of the social parameters around its deployment.

\section{Framework: Relationalities between Formal and Social Order}

Neighbourhoods built in the wake of New Urbanist efforts over the last 30 years are beginning to mature around the world. As they do, discontent with the extent of their effectiveness toward generating various notions of the common good life-and, especially, contestations about their entanglement with the good community-have fuelled debate between practitioners and theorists on what the next phase of urban development ought to entail (Talen, Menozzi, \& Schaefer, 2015). In many ways, such debate within and surrounding New Urbanism is not new. From the earliest conceptions and implementation of New Urbanism, there has been both internal debate as to what New Urbanism is committed to and external debate as to its merits (Thompson-Fawcett, 2003a).

Those operating from an advocacy platform-New Urban protagonists and practitioners-postulate that the best cities have been composed of something akin to the New Urban neighbourhood type, but that modern culture and/or modern development-to varying degrees-have exacerbated a growing rift between alienated individuals and the common good (Duany, Plater-Zyberk, \& Alminana, 2003; H. R. H. Prince of Wales, Juniper, \& Skelly, 2010). Most of these actors consider the compact neighbourhood to be an essential framework that enables good social order to follow, but show increasing propensity for social engineering or trying to 'build' intentional communities-sometimes through 'community-led' design processes-as evidence emerges that the anticipated social order does not tend to follow (Taylor \& Levine, 2011; Thompson-Fawcett \& Bond, 2004).

Some research has shown that New Urbanist efforts tend not to result in the encouragement of citizens who are more inclined to go out of their way for neighbours, and that their capitalisation can, in fact, exacerbate the individualism and exclusivity they were meant to combat (Macleod \& Johnstone, 2012; Thompson-Fawcett, 2003b). In other words, the "spatial rhetoric" of New Urbanism "fails to correct the material consequences" of modern development (St. Antoine, 2007, p. 142) and social evolutions of contemporary life.

Many of those operating from a cautionary platform-social scientists and theorists-critique New
Urbanist discourse as nostalgic or deterministic and, therefore, questionable when it comes to proposing ways in which human beings might live meaningfully in relation to one another (Bond \& Thompson-Fawcett, 2007; Jarvis \& Bonnett, 2013). Consciously employing urban form to help reinforce the earlier stated goals of community identity, responsibility and protection can produce a conformity that eliminates diversity and blocks social change (Harvey, 1997). Yet such discourse underpins the processes and outcomes associated with much of contemporary neighbourhood development; and prominent examples tend to be thosesuch as Poundbury in Britain-through which designers have been able to showcase 'participatory' processes, yet nonetheless keep a "tight rein" over the "physical structure" (Thompson-Fawcett, 1998, p. 191). Thompson-Fawcett has challenged place-makers to "be aware of [social] implications" associated with this "tight rein" of Krier and other New Urban protagonists (Thompson-Fawcett, 1998, p. 191). Although a handful of researchers have since challenged cohesive architectural ensembles as "maintain[ing] a visual homogeneity through a strict aesthetic regime in which social differences are either contained or simply excluded" (Pow, 2009, p. 382), the architecture of New Urban neighbourhoods remains curiously under-examined, particularly in relation to professional practitioner conceptions or residential lived experiences. In other words, not enough research has examined how and why individuals conceptualise or live in relation to the 'tightly reined' formal aesthetics associated with such neighbourhoods, and how this form relates to the communication of social processes and meanings.

Despite the realisation of New Urbanism's shortfalls, and important contributions made toward unveiling authoritarian undertones of New Urbanist discourse and problematising 'participatory' planning processes (Bond \& Thompson-Fawcett, 2007; Grant, 2009), debates surrounding the New Urban neighbourhood type have tended to settle into a kind of holding pattern. Social scientists unveil the shortcomings within academic circles, but largely fail to impact its popularity as a practical type used widely in placemaking efforts (Fainstein, 2010; Næss, 2015). Likewise practitioners, confident in their approach, largely fail to engage with pertinent research or heed research-based precautions (Grant, 2006).

A more-than-relational approach that recognises the agency or causal capacity of both human persons and built form in relation to each other and to larger discourses or structures (Næss, 2015) can help re-evaluate the situation. We propose a fresh evaluation of the subtle, complex and sometimes contradictory interweavings of individuals with each other and with their neighbourhoods, starting with Stockholm. Doing so with particular attention given to the New Urban neighbourhood as a material entity, with its own causal and communicative capacity in relation to the social lives of its inhabitants, can help practitioners and social scientists move beyond the 
elusive 'good community' and unveil alternative notions of meaningful coexistence. In other words, complex relationalities between formal and social order may be more easily revealed when individuals and built form are recognised for their agential capacity and allowed some distance from associations more commonly espoused in dominant discourse and, thus, critique (Riemer, 1951). In this inquiry, particular attention is given to the role of cohesive architecture-as a defining characteristic of New Urban neighbourhood form-in person-person relationalities, so as to reveal its role in the communication and co-creation of social meanings with design conceptions and lived experiences.

In busy, networked mongrel metropolises (Sandercock, 2003)-where derivations of the New Urban neighbourhood are growing in popularity as a practical strategy for good urban development-the role of built form is likely to stray from idealistic or narrow conceptions of community espoused in New Urbanist discourse and, thus, critiqued by social scientists. Building on the communitarian debate between practitioner and theorist spheres is valuable if placemakers are to unveil latent roles that neighbourhood types might play in the communication and co-creation of social meaning with individually-motivated interpersonal actions of busy, networked individuals.

Farias (2010, p. 1) asks geographers and other social scientists to develop "new insights into the city" by engaging with new "theoretical tools" that can better probe the ever-perplexing relational space between people and between people and the built environment. Such tools enable a city and the neighbourhoods that comprise it to be understood as sites of intersection between "network topologies" - such as the interweavings of New Urbanism's advocates and cautionaries-and "territorial legacies" - the physical, political or other boundaries that delineate one place from another (Amin, 2007, p. 103). The result is "a subtle folding together of the distant and the proximate, the virtual and the material, presence and absence, flow and stasis, into a single ontological plane" (Amin, 2007, p. 103). The benefit of focusing on such intersections is that relationships take priority over differences and new insights into city-making can emerge above and beyond discursive or procedural debates.

Hence, we ask what is the urban neighbourhood as an architectural body, a material entity with communicative and causal capacity intertwined with-yet also distinct from-the relations, such as dominant New Urbanist discourse, of which it is a part? Who are the people with whom urban neighbourhood form becomes relationally reticulated, either through design actions or through residential opportunity? Whether architectural or human, each of these bodies is positioned within an assemblage of relations. The important distinction is that these relations are not themselves agents and therefore cannot "claim prior knowledge of what the powers of a particular object or entity can necessarily do"
(Allen, 2012, p. 191). Their effects on a given body may be benign or malign (Sayer, 2000). There is an "emergent 'thingness' beyond relational effects" of neighbourhood form and the people associated with it. They have "capacities or powers which are not exhausted by the relations of which they are a part" (Allen, 2012, p. 191). Human beings navigate interpersonal and environmental relationships with unique internal compasses. Our investigation examines critical relationalities-specifically in New Urbanist discourse and Sweden as a unique cultural context-of which participants and the neighbourhoods they inhabit are a part. Yet throughout the examination, human and architectural bodies are ontologically re-vindicated as entities with agency and the capacity to resist or even transcend relational influences. In this article, each case study is considered to be an architectural body with causal capacity (Næss, 2015), not the mere sum of its associated relations with larger discourses or structures. What this means is that New Urban neighbourhoods "are made up of powers that have the potential to be actualised differently depending upon the relations of which they are a part and such arrangements may even throw up new capacities" (Allen, 2012, p. 191). We also challenge critiques that overlook the unique conceptions of individual designers in relation to larger discourses or that dismiss residents as mere consumers only interested in purchasing a 'safe' or 'nostalgic' citizenship (Jarvis \& Bonnett, 2013). Not just neighbourhood form, but also those individuals who design or experience that form ought to be recognised as being "made up of powers that have the potential to be actualised differently" (Allen, 2012, p. 191). Each designer ought to be recognised as having their own internal agency and, thus, the power to choose how to engage-if at all-with widespread discourses. Similarly, if it is true that architecture and the "numerous flows of cultural events, contexts, desires and feelings" within which it is enmeshed "are erratically mutually informative, with loose and porous borders," then each neighbourhood resident might be considered more than just a "consumer...of mediated [architectural] messages" (Crouch, Jackson, \& Thomas, 2005, p. 12). Each individual's agency and unique imagination plays a significant role in the acting, ignoring, rejecting, reacting or negotiating of larger discourses or structures surrounding them on a daily basis. Moreover, various depths of meaning are possible in relation to the built environment and range from the 'explanatory' to the 'revelatory' (Thoren, 2010), suggesting the capacity of architectural bodies to stir an individual-or not-and thereby play some causal or communicative role in their person-person and personenvironment relationalities.

\section{Approach and Methods}

In this study, we took a multimethodological approach that relied most heavily on semi-structured and conversational interviews (five with designers and 54 with resi- 
dents/visitors), but also interweaved observation, solicited diaries and self-directed photography (six participants), as per Table 1. The designer interviewees were key informants chosen for their role in developing the two case neighbourhoods. The residential interviewees were a convenience sample based on willing participants, covering a mix of ages, gender, ethnicity, education and occupation. The conceptual approach underpinning the multimethodology was critical realist in its ontology and more-than-relational in its epistemology. The research was undertaken in Stockholm with the stance that both the material (e.g., built form) and the immaterial (e.g., conceptions and lived experiences) are equally real and have significant capacities in relation to each other and larger structures or discourses (Næss, 2015). These real entities and the relationalities within which they are situated are knowable (albeit indirectly) and worth knowing (to a realistic extent and recognising important limitations). Reception theory provides a framework useful in the development of such morethan-relational understanding (Thoren, 2010). This multidisciplinary conceptual approach encourages less typical examinations of the way in which individual designers conceptualise and individual citizens experience neighbourhood form in relation to-yet variously removed from-the influence of dominant discourse and structures. The intention is that such examinations might unveil new meanings, especially those which are deeply moving or meaningful (Thoren, 2010) and somehow intertwined with evolving notions of sociality and everyday coexistence (Cloke, 2002).
The research study is case-based, and examines the conceptions and lived experiences of two urban developments in Stockholm, Sweden, that exemplify formal characteristics of the New Urban neighbourhood type. Alongside the United States and Britain, Sweden has played a leading role in the New Urbanist movement. Many New Urban developments are maturing across the Swedish landscape, yet it is an under-researched and potentially illuminating context. In addition, Sweden has a strong reputation of leadership in matters of social and environmental sustainability; for example, in developing the Passive House standard (with Germany), striving to create model green communities, and even aiming to be the world's first oil-free nation (Edwards, 2010). It makes sense, then, to examine New Urban developments striving toward a notion of the common good life encompassing social and environmental sustainability in Sweden, for the benefit of international urban design and architectural praxis. Thus, two developments that had both been internationally recognised as embodying New Urbanist principles (Cramer \& Yankopolus, 2005; Gaffney, Huang, Maravilla, \& Soubotin, 2007) were identified for investigation: Sankt Erik and Hammarby Sjöstad in Stockholm. These developments are paradigmatic in their common goal of supporting good urban life, yet divergent in their strategies for achieving this goal, as evidenced in contrasting (classical and modern) architectural approaches. The classical language employed at Sankt Erik is inspired by the ideology of Leon Krier, who has been instrumental in propagating the organic metaphor (Thompson-Fawcett, 1998) and conservative

Table 1. Research activities with participants.

Research activities with participants

number

Design participants (architects and urban planners)

Interview/s 1-1.5 hour

5

The interview (in one case a series of two interviews) involved a semi-structured approach covering histories, 2 (SE)

design intentions, architectural language, urban form, processes, built reality, feedback, etc.

Residential participants (residents of/visitors to SE/HS)

Primary interview $0.25-1$ hour

The primary interview was based on a semi-structured approach covering reason for living in SE/HS,

experience of living here, opinions on architecture/daily life/community, comparison with other places,

etc. Participants were invited to participate in keeping a diary/photography.

Solicited diary/photography 0.5 hours/day $\times 10$ days

6

The diary was semi-structured with simple daily prompts. Participants had a choice of keeping an

analogue (paper) diary or digital (online) diary. Participants were prompted to write about their

neighbourhood, buildings, spaces, lifestyle, connections, attachment, nature, spirituality, sustainability, future, etc. A disposable camera was also provided (unless residents preferred to use their own camera or phone) to record relevant imagery related to each diary prompt. At the end of the diary-keeping process, participants were invited to participate in a final interview.

Post-diary interview $0.5-1$ hour

The post-diary interview involved an inquiry/discussion about the participant's diary responses. 
notions of human and environmental flourishing (H.R.H. Prince of Wales et al., 2010). In contrast, Hammarby Sjöstad is articulated through clean lines and modern green technologies, which might be characterised as a more liberal and progressive approach. By examining the narratives of expected transformation that architectural and urban designers have embedded in the built form of Sankt Erik and Hammarby Sjöstad, how these stories (or the symbols that are meant to represent and communicate them) are interpreted by individual citizens as they go about their everyday lives, we may begin to better understand what role neighbourhood form plays in nurturing future stories of human and environmental flourishing. The two developments (Figure 1) not only exemplify the realisation of New Urban typological characteristics in built form, but also control for stylistic variation in the consideration of architectural cohesiveness. In other words, both developments are composed of formal variations derived from the typological standards popularised by Krier (2009) and his contemporaries (Congress for the New Urbanism, n.d.; Duany et al., 2003).

Both developments are distinctive, yet take divergent approaches in their cohesive display of architec- ture: Sankt Erik buildings are designed from a common vocabulary derived from 'Swedish Grace' or 1920s classicism (Elmlund \& Martelius, 2015), whereas Hammarby Sjöstad buildings feature common elements-large windows, clean lines, generously-scaled openings-for a more modern aesthetic. This difference between the two developments has helped concentrate findings on the tension between visual and social conformity, rather than get lost in aesthetic debates (Talen \& Ellis, 2004). Any number of case studies could have been selected. By selecting two examples already identified as best practice on many levels such as design and sustainability, we did not seek 'representative' analysis, rather we were able to undertake an in-depth analysis of values, intent, perspectives and lived experiences. And by selecting disparate cases, we had the opportunity to interpret contrasts in the contemporary expression and evolution of New Urbanism. Furthermore, and so as to unveil new insight, these case studies were chosen because of the wider context in which they are embedded: Stockholm, which (as previously noted) is home to some of the world's most quintessential realisations of urban neighbourhood form from the early $20^{\text {th }}$ century. Sankt Erik

\section{SANKT ERIK} (within Kungsholmen)

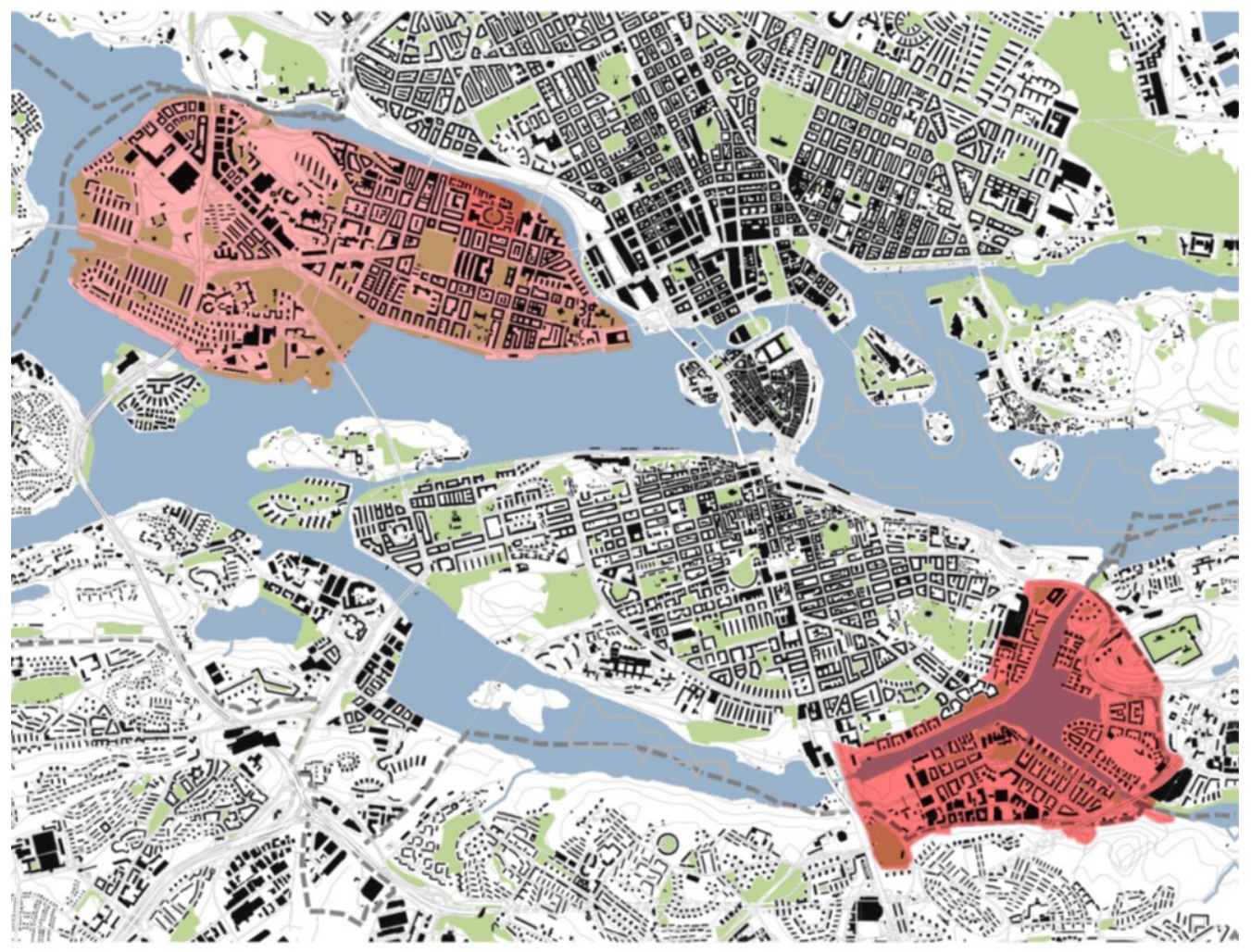

\section{HAMMARBY SJÖSTAD}

Figure 1. Case study locations in Stockholm. 
and Hammarby Sjöstad exemplify formal characteristics derived from $20^{\text {th }}$ century ideals and typified in the New Urban neighbourhood under consideration, while their situatedness in Stockholm reinforces the possibility of this study revealing new understandings of urban sociality. Such understandings are derived from a development context that also enthusiastically encapsulates the Swedish concepts of mysig (being cosy and content at home) and lagom (a place with just the right balance) in the design. The investigative aim is not to unveil or validate any objectively 'right' way to build neighbourhoods or achieve 'good,' sustainable communities, nor is it to emphasise the irreconcilability of individual conceptions and experiences of New Urban neighbourhood form. It is to examine how the formal type is conceptualised and experienced in Sweden, so as to contribute to wider deliberations about the relevance of a historicallyderived form in relation to emergent-and sometimes divergent-notions of contemporary sociality or meaningful coexistence.

The analysis of designer and residential interviews, diaries and photographs was based on a grounded theory approach to coding anchoring points and categorising key concepts and themes as they emerged from the data. Minichiello, Aroni, Timewell, and Alexander's (1990) procedures were particularly well-suited to dealing with such breadth of manifest and latent content. To begin we reflexively evaluated the data to the degree that was possible in the field by observing and keeping notes. Such evaluation allowed for the generation of "insightful propositions" that may not have been "readily apparent" in specific interactions (Minichiello et al., 1990, p. 277), but that clarified linkages between responses and significantly underpinned the thematic structure of the analysis. In other words, through field notes recording observations and initial linkages between participant accounts, we began to unveil themes encircling architecture's role in urban environments as a communicative mediator of that which is connected and separate. The development of themes began with the first interview and was refined throughout the process until after the last interview. In this way, the findings presented below have generated the key concepts that explain the way that queried designers and residents have resolved the meaning attached to the two case study neighbourhoods.

\section{Findings: Sankt Erik and Hammarby Sjöstad}

\subsection{As Conceived}

Echoing prevalent critiques within social science, our interviews with designers in Stockholm confirm cautionary tales of New Urbanism's failure to resolve the economic and social hegemony plaguing urban development. Aleksander Wolodarski and Jan Inghe-Hagströmthe urban planners of Sankt Erik and Hammarby Sjöstad, respectively-were influenced by the work of New Urbanists (Hall, 2009). However, for example, there is something about the formal composition-the rawness of form detached from any sort of agenda or purpose other than that to inspire in the way that music inspiresthat captures Wolodarski's imagination. Wolodarski indicated during our interview that early in his career he read a lot of publications by Leon Krier and his predecessors, which led him to believe that he "must plan in different ways" to what he saw being built around him at the time. Yet, despite his excitement that Sankt Erik has subsequently been formally recognised by the Congress for New Urbanism (Cramer \& Yankopolus, 2005) and its main protagonist, Andres Duany, as well as by the Prince's Foundation for Building Community and its main protagonist, HRH The Prince of Wales (The Prince's Foundation, 2012), Wolodarski is hesitant to attach the formal design of Sankt Erik definitively to such a 'movement.' For example, Wolodarski has made a formal gesture to distinguish 'public' from 'private' in his design of the central urban space within Sankt Erik, very much in the manner of New Urbanists, who value landscapes that are typologically legible, yet without the expressed intention of 'promoting' community. He seeks to maintain a social fluidity between human bodies and built form, rather than assume a particular social outcome.

In the case of Hammarby Sjöstad, notwithstanding Krier's influence in particular, Inghe-Hagström deviates from certain norms within New Urbanist rhetoric that emphasise notions of 'street life' (Talen, 1999) or 'vitality' (Tunström, 2007) as indicators of achieving a common good life. In response to local critiques of Hammarby Sjöstad as not being adequately 'vital' or 'city-like,' Inghe-Hagström, counters by indicating that life can unfold in a variety of nuanced ways outside of public display. He values the tactility of spaces that people occupy, particularly those which are "green and quiet, peaceful and beautiful" (Hultin, Pontvik, \& Söderlind, 1992, p. 26). Vibrant social life may occur, but likewise there may be other experiential outcomes, such as tranquil reprieve from inner-city pressure. So, although influenced by, and in dialogue with, Krier, Inghe-Hagström's recorded accounts suggest his hesitance to promote an idealised view of community life through built form. Again, like Wolodarski, his design cues social fluidity rather than prescribed social effect.

Designer descriptions of the neighbourhoods they shaped as environments in which individuals might seek reprieve from the chaos and complexity of modern metropolitan life differ from oft-stated goals of principal New Urban protagonists. While inspired by New Urbanist design in a formal capacity, the designers in Stockholm do not share the enthusiasm for engendering community in the same way. Wolodarski and Inghe-Hagström are hesitant to attach any particular social order to the architecturally cohesive formal order they espouse. A certain level of organisation between people is understood as necessary, but only so far as practicality requires. In both their interactions with with New Urban protagonists and their discourse, and in their expectations 
about the social life of Sankt Erik and Hammarby Sjöstad, the designers prefer the interpersonal in moderation. This kind of moderate approach to compact neighbourhood design in Sweden is unique in that it contrasts with approaches more common in Britain or North America (Grant, 2007). The preference for a level of formal and social interaction that is not uninhibited, yet equally not unsociable, may help illuminate the possibility of more-than-relational approaches to understanding urban development. Similar to the way "the 'garden city' came to be regarded as a building pattern rather than a social concept" in early-20 ${ }^{\text {th }}$-century Sweden (Hall, 1994, pp. 164-165), so too are building-rather than social-patterns the concern of Stockholm designers today. Figures 2 and 3 reflect this formal pattern, showing a stylistic variation between the developments, but the architectural cohesiveness within each.

The New Urban neighbourhood is "a phenomenon anchored in the mind" whose spatial delineations and relationships "are subject to different interpretations" (Riemer, 1951, p. 35). Or, as Westin (2014, p. 52) phrases it, planners' "statements reflect [their] perspective" in relation to the design conception. Lefebvre (1991) and those following in his footsteps have posited, "every society creates its own space" (Madanipour, 2003, p. 81). Such spaces may be understood as having symbolic significances linked with human perception (Gesler, 2005). There is a certain way in which the people of each
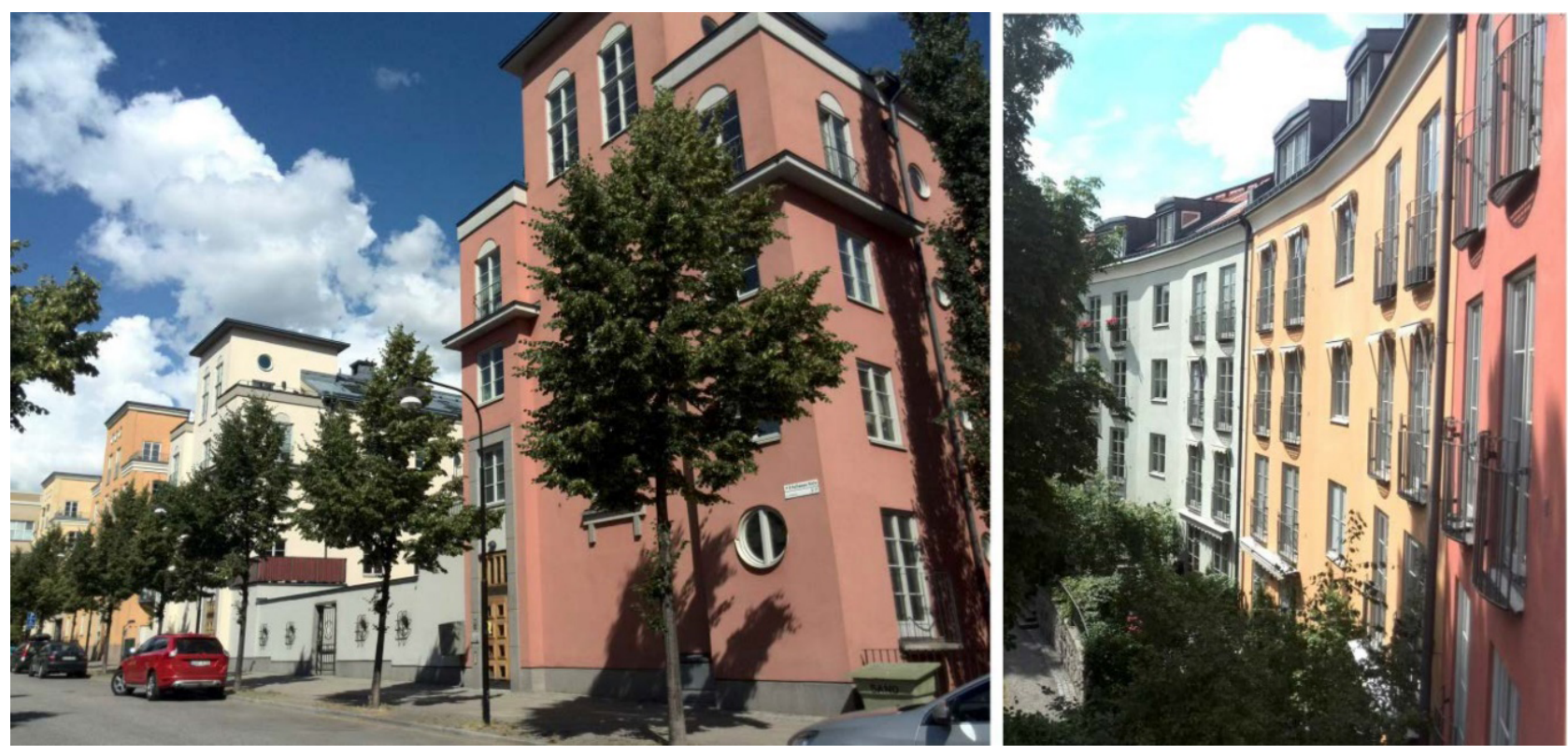

Figure 2. Sankt Erik. Source: Authors.
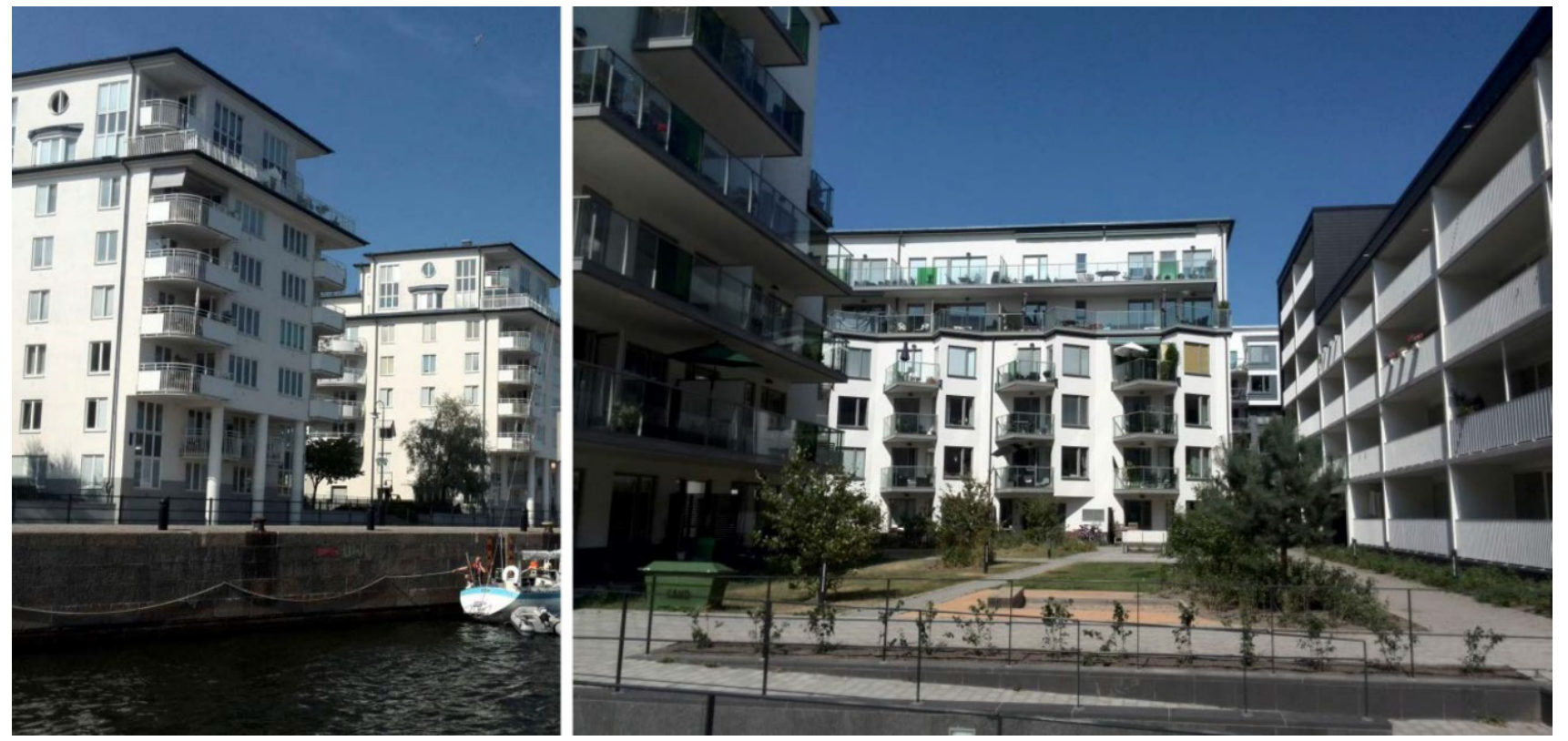

Figure 3. Hammarby Sjöstad. Source: Authors. 
society think of and organise themselves-formally and socially-that is distinct from other societies. This distinction is sometimes subtle and, in such cases, easily overlooked, particularly when overarching commonalities are given more weight than individual agency. The formal and social motivations behind Sankt Erik and Hammarby Sjöstad have, in the past, been overlooked in their subtlety. Although plainly influenced by Leon Krier and the New Urbanist movement, New Urbanism has not been translated in a prescriptive manner into the Swedish context (Marcus et al., 2013). The unique motivations and agency of individual designers navigate and influence the discourses with which they are associated.

\subsection{As Experienced}

In this section, we present findings from the analysis of interview, diary and photographic data gathered from individuals who experience Sankt Erik and Hammarby Sjöstad. We pay particular attention to their human agency in relation to both local and widerStockholm contexts.

Our resident and visitor informants in the two developments prioritise a kind of fluidity between social isolation and connectedness. Their simultaneous comfort with and resistance to collectivism emerges as a strong theme in verbal, written and photographic accounts of how they act in relation to the human and architectural bodies that surround them. Access to a quiet reprieve in proximity and contrast to the 'big city atmosphere'with its cultural activities, nightlife, traffic-is more than just a motivating factor for choosing to live in Sankt Erik or Hammarby Sjöstad. It can have a significant impact on their daily rhythms and relational experiences (Pierce, Martin, \& Murphy, 2011). In both developments, the lived experiences of formal connectedness and formal separateness overlap. The New Urban neighbourhood form plays a mediative role in dividing and connecting persons in the Stockholm context. This role, however, does not neatly align with the widespread expectations of New Urban practitioners. Those connected tend not to be connected within each particular neighbourhood, as New Urbanists might hope or advocate for; social bonds are highly networked and dependent on more than proximity alone (Meegan \& Mitchell, 2001). Feelings of containment within that which is compactly arranged and visually cohesive illuminate the need for such urban spaces not necessarily for collective gatherings, but for individual moments of restoration-sometimes bordering on the spiritual-within larger contexts flooded with social expectation. As such, the social separateness that the New Urban neighbourhood type mediates in the two developments is temporary and fluid. This reprieve that such formal containment offers plays an important role in enabling individuals to cope or maintain a balance with their ongoing participation in larger or more dispersed social networks, structures and landscapes. The reprieve offered by formal containment is neither a full retreat from nor dismissal of larger Stockholm or social responsibilities; rather it speaks to a sensibility that many Swedes have toward participation in the whole, and contributes to the notion of 'porosity' in emerging ideas of 'good urbanism' (Ellin, 2013).

Residents' accounts of their lived experiences in relation to the social order of each development display an almost equal-and overlapping-emphasis on that which is connected or collective and that which is separate or individual. Accounts from Sankt Erik and Hammarby Sjöstad residents are strikingly similarexpressing concern for individual autonomy in proximity to others, see Figure 4. Our informants tend to keep to themselves and value being socially separate. Yet they simultaneously value the (buffered) presence of other human beings and the sensation that they are part of some larger 'whole.' This buffered way of being together is considered by some residents to be more authentic in that it encourages 'free relations' rather than sociality boxed in by pressures to conform (Booth, 2014). The notion of 'community' - particularly that which is geographically bounded-is off the radar for many of our informants. The ability to accommodate both that which we present to the world and that which we choose to keep quiet is a particular strength of built form that resonates with the Swedish psyche. Moreover, New Urban neighbourhood form is thriving as a typological paradigm for good development in Sweden (Tunström, 2007), despite a lack of interest in neighbourhood-engendered community.

This particular formal type has a long history of cross-cultural migration and adaptation that has most recently been articulated by New Urban protagonists. Yet despite global popularity for the cohesive formal order of such compact neighbourhoods (Grant, 2006; Thompson-Fawcett, 2003a), correlating social orders have yet to follow convincingly (Macleod \& Johnstone, 2012). The 'successful' contemporary experiences of this type can be re-conceptualised. Although architectural bodies-such as the New Urban neighbourhoodcannot effect social cohesion or isolation, they do have some agential-causal or communicativecapacity (Næss, 2015) and can serve as mediators between the individual and metropolitan complexities of lived experience.

\section{Discussion: Recognisable but Differentiated Urbanism}

Our empirical findings challenge dominant New Urbanist conceptions about the anticipated correlation of formal and social order. The designers of the two case study developments do not attach community ideals to neighbourhood form in the same way as their British and North American counterparts. Rather, built form is expected to play a complex role in safeguarding the autonomy and "pure relationships" (Giddens, 1991, p. 90) of individuals within a collective. Accounts of 


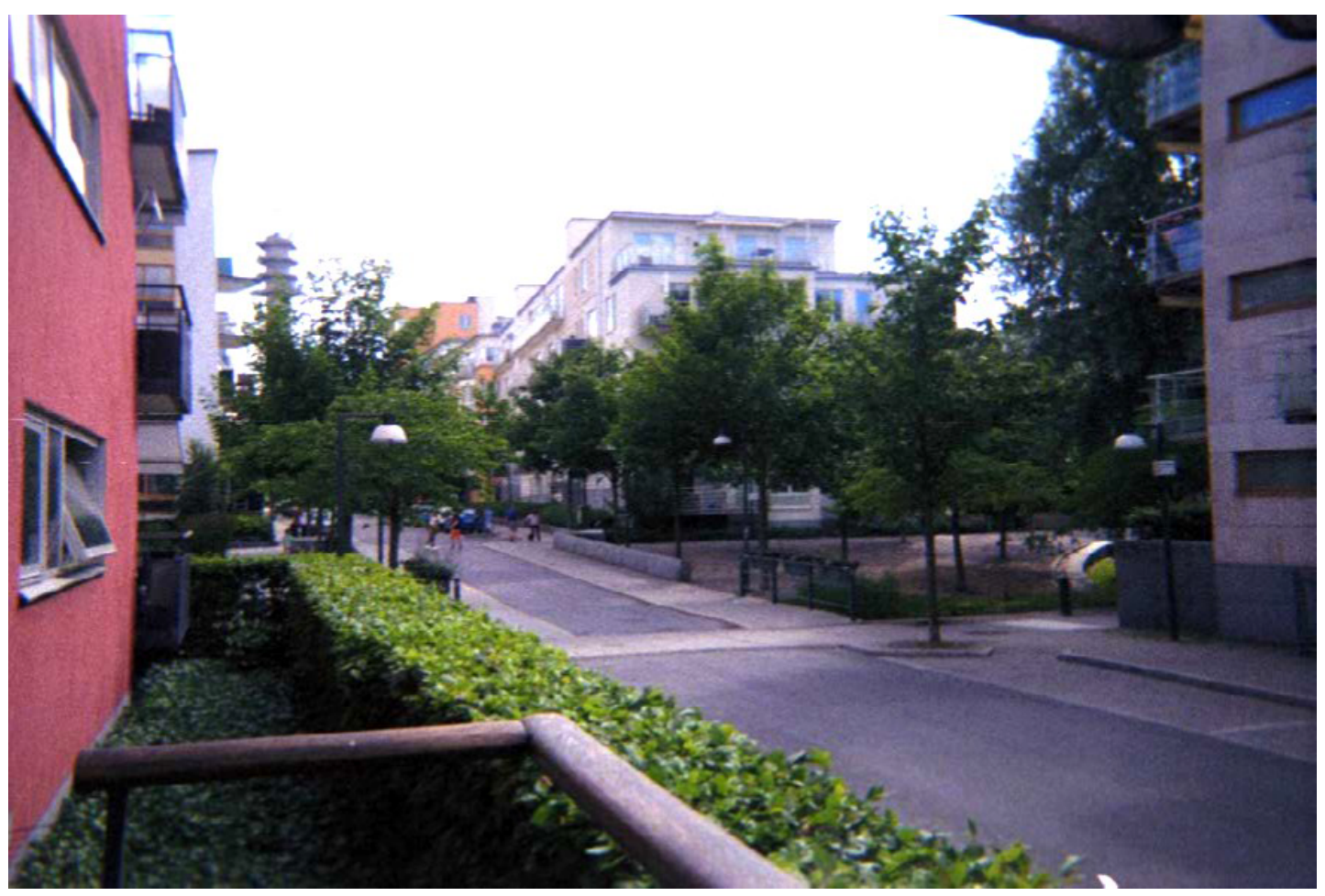

Figure 4. Resident's photo of their private space that views the public realm. Source: Authors.

lived experience in relation to Sankt Erik and Hammarby Sjöstad display a similar fluidity in the navigation of human and architectural bodies.

So what role does New Urban neighbourhood form play in regard to social order when our urban contexts are increasingly plural, variously meaningful, and citizens are confronted "with diversity on a daily basis," particularly "in large metropolitan areas" (Van Leeuwen, 2013, p. 2)? Built form-particularly that which is cohesivehas a tendency to fade into the background and become a neutral container of, or autonomous body in relation to, lived experiences. While no doubt disappointing to many architects, this notion may reveal something hopeful about human existence. Theorists have long acknowledged that a focus on the material-a direct longing for the aesthetic in-and-of itself-can exacerbate human dissatisfaction; whereas a focus on the experiential-with, for example, aesthetics serving as a backdrop-can contribute to high levels of human satisfaction or contentedness, which in turn contribute to various realisations of the 'good life' (Van Boven, 2005). Recognising the fragility of political culture that has developed in Sweden from the 1980s (Ruth, 1984) and correlating wariness of social conformity, Swedish designers have erred on the side of caution when it comes to imbuing their developments with preconceived social meaning. Thus despite formal ordering ambitions that parallel those in Britain and North America, Swedish designers have maintained a discursive distance from dominant New Urbanist conceptions of a resulting social order or good community.

Sankt Erik and Hammarby Sjöstad are well-loved by residents and visitors not for evoking a sense of commu- nity that harks back to bygone eras of solidarity; neither are they coveted materially as possessions that flaunt an individual's consumer status. Participant accounts reveal social meanings in-between more polarised notions of connectedness and separateness that New Urbanist discourse has been critiqued for in relation to other contexts (Thompson-Fawcett \& Bond, 2003; Wissink, van Kempen, Fang, \& Li, 2013). Residents experience New Urban neighbourhood form as a meaningful way of navigating and transitioning between public and private spheres; they value a relational balance communicated or mediated through cohesive-yet porousarchitectural assemblages. One way to understand these relationalities is as contextually specific to Sweden, whose political structure is materially echoed at an architectural level.

The findings of our investigation, then, might be understood as prompts for wider deliberation about the complex processes of becoming human (Deleuze \& Guattari, 1988) in relation to built form and contemporary notions of sociality. Despite global popularity for the cohesive formal order of New Urban neighbourhoods (Grant, 2006; Thompson-Fawcett, 2003a), correlating cohesive social orders have yet to follow in contemporary contexts (Macleod \& Johnstone, 2012). Participant accounts of why and how people have conceptualised and/or experienced this formal type in Stockholm challenge both practitioners and theorists to re-conceptualise how the formal and social might be better understood in relation to one another in other urban contexts. What our Stockholm study has revealed is that neighbourhood form can participate in the com- 
munication and co-construction of social meanings; it is not meaningless or arbitrary. Importantly, however, these meanings are co-constructed through professional conceptions and individual experiences, tend to be fluid and textural rather than fixed or textual (Leach, 1997), and may be limited to that which can buffer or mediate relationalities. We suggest it is important that practitioners and theorists alike challenge neighbourhood conceptions such that the agency of built form is acknowledged, but not over-stated.

\section{Conclusions}

Architects, designers and planners ought to remain open to how and what meanings their designs communicate and co-construct-figuratively, emotionally, spiritually or otherwise-with those who live in relation to them. Such openness makes sense practically, too, since there is a limit to "how far...ideas and theories [can] assert themselves," particularly given the complex processes associated with contemporary urban building (Hall, 1994, p. 165). Culturally varied experiences of built form that contribute to the co-construction of meanings, comparable to the Swedish-specific preferences articulated by our research participants, will occur in other urban contexts. Since form co-constructs meaning in relation to a variety of conceptions and experiences, it is important that placemakers "look to multiply...our readings of the city" (Leach, 1997, p. 158), particularly in their depth so as to unveil deep experiences involved in the co-creation of social meanings.

Finally, our research in Stockholm is an illustration of the heterogeneity associated with the New Urbanism movement. That heterogeneity, in part born of the specifics of locations and histories, challenges any notions that New Urbanism is a singular, univocal paradigm. There is a plurality of values and voices diversifying the language and implementation of New Urbanism in the contemporary city. The two Stockholm case studies demonstrate a partial and contextualised application of the formal principles of New Urbanism for neighbourhood development. And, despite the distinctive application and preference on the part of the designers to avoid being labelled as part of any movement, the resulting neighbourhoods embody an architectural lineage and built form that connects them directly with New Urbanism. The way in which our Stockholm case studies deliver a recognisable, albeit differentiated New Urban package suggests that the New Urbanism label retains relevance, especially in terms of disclosing the often veiled meanings behind the built environment as conceived, experienced and perceived. They are also an expression of the need to keep pace with the customised ways in which New Urbanism is having influence. The movement has evolved and diffused over time, and it has become diversified in the place-specific enactments of its tenets and mission.

\section{Acknowledgments}

We are grateful to the anonymous referees for their very helpful suggestions.

\section{Conflict of Interests}

The authors declare no conflict of interests.

\section{References}

Allen, J. (2012). A more than relational geography? Dialogues in Human Geography, 2(2), 190-193.

Amin, A. (2007). Re-thinking the urban social. City, 11(1), 100-114.

Ancell, S., \& Thompson-Fawcett, M. (2008). The social sustainability of medium density housing. Housing Studies, 23(3), 423-442.

Bond, S., \& Thompson-Fawcett, M. (2007). Public participation and new urbanism: A conflicting agenda? Planning Theory \& Practice, 8(4), 449-472.

Booth, M. (2014). The almost nearly perfect people: Behind the myth of the Scandinavian utopia. New York, NY: Picador.

Cloke, P. (2002). Deliver us from evil? Prospects for living ethically and acting politically in human geography. Progress in Human Geography, 26(5), 587-604.

Collins, G. R., \& Collins, C. C. (1986). Camillo sitte: The Birth of Modern City Planning. Mineola, NY: Dover.

Congress for the New Urbanism. (n.d.). The movement. Congress for the New Urbanism. Retrieved from https://www.cnu.org/who-we-are/movement

Congress for the New Urbanism. (1996). The charter of the New Urbanism. Congress for the New Urbanism. Retrieved from https://www.cnu.org/who-weare/charter-new-urbanism

Congress for the New Urbanism. (2018). The 25 great ideas of the New Urbanism. Washington, DC: Congress for the New Urbanism. Retrieved from https://www.cnu.org/sites/default/files/25-greatideas-book.pdf

Cramer, J., \& Yankopolus, J. (2005). Almanac of architecture and design 2005 (6th ed.). Norcross, GA: Greenway Communications.

Crouch, D., Jackson, R., \& Thomas, F. (2005). Introduction. In D. Crouch, R. Jackson, \& F. Thomas (Eds.), The media and the tourist imagination (pp. 1-13). New York, NY: Routledge.

Deleuze, G., \& Guattari, F. (1988). A thousand Plateau's: Capitalism and schizophrenia. London: Athlone Press.

Demerath, N. J., III. (2000). The rise of "cultural religion" in European Christianity: Learning from Poland, Northern Ireland, and Sweden. Social Compass, 47(1), 127-139.

Duany, A., Plater-Zyberk, E., \& Alminana, R. (2003). The new civic art. New York, NY: Rizzoli. 
Edwards, A. R. (2010). Pathways to a resilient society. Gabriola Island: New Society Publishers.

Ellin, N. (2013). Good urbanism. Washington, DC: Island Press.

Elmlund, P., \& Martelius, J. (Eds.). (2015). Swedish grace: The forgotten modern (1st ed.). Stockholm: Ax:son Johnson Foundation.

Fainstein, S. (2010). The just city. Ithaca, NY: Cornell University Press.

Farias, I. (2010). Decentring the object of urban studies. In I. Farias \& T. Bender (Eds.), Urban assemblages: How actor-network theory changes urban studies (pp. 1-24). Oxon: Routledge.

Gaffney, A., Huang, V., Maravilla, K., \& Soubotin, N. (2007). Hammarby Sjostad, Stockholm, Sweden: A case study. Retrieved from http://www.aeg7.com/ assets/publications/hammarby\%20sjostad.pdf

Gesler, W. (2005). Therapeutic landscapes: An evolving theme. Health and Place, 11(4), 295-297.

Giddens, A. (1991). Modernity and self-identity: Self and society in the late modern age. Cambridge: Polity Press.

Grant, J. (2006). Planning the good community: New urbanism in theory and practice. Oxon: Routledge.

Grant, J. (2007). Two sides of a coin? New urbanism and gated communities. Housing Policy Debate, 18(3), 481-501.

Grant, J. (2009). Theory and practice in planning the suburbs: Challenges to implementing new urbanism, smart growth, and sustainability principles. Planning Theory \& Practice, 10(1), 11-33.

H. R. H. Prince of Wales, Juniper, T., \& Skelly, I. (2010). Harmony: A new way of looking at our world. London: Harper Collins.

Hall, T. (1994). Planning history: Recent developments in the Nordic countries, with special reference to Sweden. Planning Perspectives, 9, 153-179.

Hall, T. (2009). Stockholm: The making of a metropolis. New York, NY: Routledge.

Harvey, D. (1997). The new urbanism and the communitarian trap. Harvard Design Magazine. Retrieved from http://www.gsd.harvard.edu/hdm/harvey.htm

Hultin, O., Pontvik, A., \& Söderlind, J. (1992). Staden, vatthet och planerarna [The city, the water and the planners]. Arkitektur, 1, 22-31.

Jarvis, H., \& Bonnett, A. (2013). Progressive nostalgia in novel living arrangements: A counterpoint to neotraditional new urbanism? Urban Studies, 50(11), 2349-2370.

Keyes, D. (2015). Green and white space invaders: New urbanism in the Okanagan, British Columbia. Home Cultures, 12(1), 83-110.

Knausgaard, K. (2015, March 11). My saga, part 2: Karl Ove Knausgaard's passage through America. The New York Times. Retrieved from https:// www.nytimes.com/2015/03/15/magazine/karl-oveknausgaards-passage-through-america.html

Krier, L. (2009). The architecture of community. Washing- ton, DC: Island Press.

Latham, A. (2003). Urbanity, lifestyle and making sense of the new urban cultural economy: Notes from Auckland, New Zealand. Urban Studies, 40(9), 1699-1724.

Lawhon, L. (2009). The neighborhood unit: Physical design or physical determinism? Journal of Planning History, 8(2), 111-132.

Leach, N. (Ed.). (1997). Rethinking architecture: A reader in cultural theory. Hove: Psychology Press.

Lefebvre, H. (1991). The production of space. Oxford: Blackwell.

Macleod, G., \& Johnstone, C. (2012). Stretching urban renaissance: Privatizing space, civilizing place, summoning 'community.' International Journal of Urban and Regional Research, 36(1), 1-28.

Madanipour, A. (2003). Social exclusion and space. In A. Madanipour, G. Cars, \& J. Allen (Eds.), Social exclusion in European Cities: Processes, experiences and responses (pp. 75-89). Oxon: Routledge.

Marcus, L., Balfors, B., \& Haas, T. (2013). A sustainable urban fabric: The development and application of analytical urban design theory. In J. Metzger \& A. R. Olsson (Eds.), Sustainable Stockholm: Exploring urban sustainability in Europe's greenest city (pp. 71-101). New York, NY: Routledge.

Meegan, R., \& Mitchell, A. (2001). 'It's not community round here, it's neighbourhood': Neighbourhood change and cohesion in urban regeneration policies. Urban Studies, 38(12), 2167-2194.

Minichiello, V., Aroni, R., Timewell, E., \& Alexander, L. (Eds.). (1990). In-depth interviewing: Researching people. Melbourne: Longman Chesire.

Næss, P. (2015). Critical realism, urban planning and urban research. European Planning Studies, 23(6), 1228-1244.

Pierce, J., Martin, D. G., \& Murphy, J. T. (2011). Relational place-making: The networked politics of place. Transactions of the Institute of British Geographers, 36, 54-70.

Porfyriou, H. (1992). Artistic urban design and cultural myths: The garden city idea in Nordic countries, 1900-1925. Planning Perspectives, 7, 263-301.

Pow, C. (2009). Neoliberalism and the aestheticization of new middle-class landscapes. Antipode, 41(2), 371-390.

Riemer, S. (1951). Villagers in Metropolis. The British Journal of Sociology, 2(1), 31-43.

Ruth, A. (1984). The second new nation: The mythology of modern Sweden. Daedalus, 113(2), 53-96.

Sandercock, L. (2003). Cosmopolis II: Mongrel cities of the 21st century. London: Continuum.

Sayer, A. (2000). Realism and social science. London: SAGE.

Smith, N. (2002). New globalism, new urbanism: Gentrification as global urban strategy. Antipode, 34(3), 427-450.

Sonne, W. (2009). Dwelling in the metropolis: Reformed urban blocks $1890-1940$ as a model for the sus- 
tainable compact city. Progress in Planning, 72(2), 53-149.

St. Antoine, T. J. (2007). Making heaven out of hell: New urbanism and the refutation of suburban spaces. Southern Communication Journal, 72(2), 127-144.

Stokowski, P. A. (2002). Languages of place and discourses of power: Constructing new senses of place. Journal of Leisure Research, 34(4), 368-382.

Talen, E. (1999). Sense of community and neighbourhood form: An assessment of the social doctrine of new urbanism. Urban Studies, 36(8), 1361-1379.

Talen, E., \& Ellis, C. (2004). Cities as art: Exploring the possibility of an aesthetic dimension in planning. Planning Theory \& Practice, 5(1), 11-32.

Talen, E., Menozzi, S., \& Schaefer, C. (2015). What is a "great neighborhood"? An analysis of APA's top-rated places. Journal of the American Planning Association, 81(2), 121-141.

Taylor, W., \& Levine, M. (2011). Building community: New urbanism, planning and democracy. In W. Taylor \& M. Levine (Eds.), Prospects for an ethics of architecture (pp. 155-180). Oxon: Routledge.

The Prince's Foundation. [PrincesFound]. (2012, March 24). The books that influenced Alexsander Wolodarsky, planner of Stockholm's Sankt Erik, visited today by Prince Charles. [Tweet]. Retrieved from https://twitter.com/princesfound/status/183211988 833411073 ? $\mathrm{s}=21$

Thompson-Fawcett, M. (1998). Leon Krier and the organic revival within urban policy and practice. Planning Perspectives, 13(2), 167-194.

Thompson-Fawcett, M. (2003a). A new urbanist diffusion network: The Americo-European connection. Built
Environment, 29(3), 253-270.

Thompson-Fawcett, M. (2003b). Urbanist lived experience: Resident observations on life in Poundbury. Urban Design International, 8(1/2), 67-84.

Thompson-Fawcett, M., \& Bond, S. (2004). Participatory community planning, urbanist style: Theory and practice at Poundbury. Open House International, 29(4), 28-37.

Thompson-Fawcett, M., \& Bond, S. (2003). Urbanist intentions for the built landscape: Examples of concept and practice in England, Canada and New Zealand. Progress in Planning, 60(2), 147-234.

Thoren, R. (2010). The deep grain of the inquiry: Landscape and identity in Icelandic art. Journal of Landscape Architecture, 5(1), 38-51.

Trägårdh, L. (1990). Swedish model or Swedish culture? Critical Review, 4(4), 569-590.

Tunström, M. (2007). The vital city: Constructions and meanings in the contemporary Swedish planning discourse. Town Planning Review, 78(6), 681-698.

Van Boven, L. (2005). Experientialism, materialism, and the pursuit of happiness. Review of General Psychology, 9(2), 132-142.

Van Leeuwen, B. (2013). Urban civility or urban community? A false opposition in Richard Sennett's conception of public ethos. European Journal of Social Theory, 17(1), 1-21.

Westin, S. (2014). The paradoxes of planning: A pyschoanalytical perspective. Surrey: Ashgate.

Wissink, B., van Kempen, R., Fang, Y., \& Li, S. (2013). Introduction: Living in Chinese enclave cities. Urban Geography, 33(2), 161-166.

\section{About the Authors}
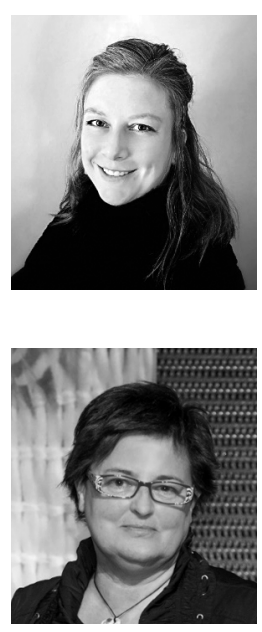

Crystal Filep is Urban Design Manager at Wellington City Council, and was previously Lecturer in Urban Design at the University of Otago, New Zealand. She has 15 years' international experience in urban design spanning across practice, research and university teaching. Crystal's research explores ways in which lived experiences can better shape conceptualisations of place that inform innovative theories and approaches to placemaking, while her placemaking efforts have ranged from large-scale masterplanning to localised revitalisation efforts and artistic interventions.

Michelle Thompson-Fawcett is a Professor in Te Iho Whenua School of Geography, University of Otago, Aotearoa New Zealand. She has 35 years' experience in planning practice and university teaching and research. Michelle's research explores urban and environmental planning activities at the local level. In particular, she examines the extent to which different groups, particularly Indigenous peoples, are able to engage in, influence, and achieve self-determination in urban and environmental decision-making. Michelle is a descendent of the Ngāti Whātua tribe. 